\title{
ARAŞTIRMA / RESEARCH \\ Üç farklı yüksek ses frekansına maruz kalmış culex pipiens (L.) (Diptera: Culicidae) larvalarında değişen mortal etkiler
}

Variable mortal effects in larvae of culex pipiens (L.) (Diptera: Culicidae) exposed to three different high sound frequencies

Halil Özkurt1 ${ }^{10}$ Hakan Kavur ${ }^{1}$ (D)

${ }^{1}$ Çukurova Üniversitesi, Karaisalı Meslek Yüksekokulu, Adana, Turkey

Cukurova Medical Journal 2019;44(3):970-976.

\begin{abstract}
Purpose: The aim of our study was to evaluate the mortality rate of Culex pipiens larvae which were subjected to ultrasonic values above and below sound frequencies.

Materials and Methods: In our lasting eight-hour experiments, 240 mosquito larvae in piezo-transducer modified vessels producing sound frequency at three different levels $(14.8 \mathrm{kHz}, 20.0 \mathrm{kHz}$ and $26.5 \mathrm{kHz})$ were used.

Results: Of the 240 Culex pipiens larvae used in our experiments, 121 of them died in all of the applied sound frequencies. The second stage larvae were found to be the most sensitive to the frequencies used. In our study, 14.8 $\mathrm{kHz}$ ultrasonic sound frequency was found to cause the highest mortality.

Conclusion: Sound frequencies under and above ultrasonic show a varying proportions mortal effect on mosquito larvae. Different mortality values show that acoustic resonance values are different among the mosquito instars. Furthermore, the high mortality rate in early stage larvae (L1 and L2) may be due to various morphological reasons.
\end{abstract}

Keywords: Culex pipiens, ultrasonic, mortality, frequency, larvae, sound

\section{GİRİŞ}

Sivrisinekler, entegre ilaçlama programlarına rağmen özellikle organik içerikli sulak alanlarda yaşamaktadırlar. Omurgalılarda görülen birçok hastalık etmenini diğer omurgalılara taşıyarak vektör eklem bacaklı tanımını sağlamış olurlar. Başta sıtma
Öz

Amaç: Çalıșmamızın amacı, Culex pipiens larvalarına farklı ses frekansları (ultrasonik değer altı ve üstü), uygulanarak, larvalar üzerindeki mortalite etkisini istatistiksel olarak araştırılmasıdır.

Gereç ve Yöntem: Toplamda sekiz saat süren deneylerimizde, 3 farklı düzeyde $(14,8 \mathrm{kHz}, 20,0 \mathrm{kHz}$ ve $26.5 \mathrm{kHz}$ ) ses frekansı üreten piezo transdüktörlü modifive kaplarda bulunan 240 adet sivrisinek larvası kullanılmıştır. Bulgular: Denemelerimizde kullanilan toplam 240 Culex pipiens larvasının 121'i, uygulanan ses frekanslarının tümünde ölmüștür. İkinci evre larvalar, kullanılan ses frekanslarına hassasiyeti en fazla olan evre olarak tespit edilmiștir. Denememizde, $14,8 \mathrm{kHz}$ 'lik ultrasonik ses frekansının, en fazla mortaliteye neden olduğu saptanmiştır.

Sonuç: Çalıșmamızda kullandığımız ses frekansları (ultrasonik değer altı ve üstü) sivrisinek larvaları üzerinde değişen oranlarda mortal etkiler göstermiștir. Farklı mortalite değerleri, sivrisinek larvaları arasında akustik rezonans değerlerinin farklı olduğunu göstermektedir. Ayrıca erken evre larvalarda (L1 ve L2) mortalitenin yüksek olması çeşitli morfolojik sebeplerden meydana gelebilmektedir.

Anahtar kelimeler: Culex pipiens, ultrasonik, mortalite, frekans, larva, ses

olmak üzere, Nil humması, Zika, Sarı humma ve filarya hastalıklarının etmenlerinin vektörlüklerini yapmaları sivrisinekler ile mücadele çalışmalarının günümüzde çok önemli olduğunu bizlere hatırlatmaktadır ${ }^{1-4}$.

Dünya sağlık örgütüne göre yılda yaklaşık 2 milyar insanın sıtma riski altında olduğu ve ülkemizde de bu Yazıșma Adresi/Address for Correspondence: Dr. Hakan Kavur, Cukurova Üniversitesi, Karaisalı Meslek Yüksekokulu, Adana, Turkey E-mail: hkavur@cu.edu.tr

Geliș tarihi/Received: 04.01.2019 Kabul tarihi/Accepted: 11.02.2019 Çevrimiçi yayın/Published online: 15.03.2019 
hastalığın özellikle Plasmodium vivax türünün neden olduğu "tersiyana sitması" şeklinin görüldüğü bildirilmektedir ${ }^{5}$. İnsanoğlu, yaşamının başlangıcından günümüze kadar sitma vektörünün rahatsızlık verici ve hastalık taşıyıcı etkilerinden korunmada, farklı yöntemler uygulayarak bu zararlı ile mücadele etmeye çalışmıştır. Sivrisinekler ile mücadele dünya çapında kimyasal, biyolojik, mekanik, kültürel ve entegre olmak üzere beş farklı şekilde yapılmaktadır. Geçmişte, sıklıkla tercih edilen kimyasal mücadele, çevreye ve hedef dışı organizmalara olan etkisinden dolayı günümüz dünyasında yerini biyolojik ve fiziksel mücadele ajanlarına birakmaktadır ${ }^{6,7}$.

Ülkemizde önceden tespit edilmiş olan 50 sivrisinek türü; Anopheles, Aedes, Ochlerotatus, Culex, Culiseta, Coquillettidia, Orthopodomyia ve Uranotaenia olmak üzere toplam 8 cins altında sinıflandırılmıştır ${ }^{8}$. Culex pipiens türleri Türkiye'de insanlara antroponotik ve zoonotik virüs ve patojenleri taşıyan onlara biyolojik vektörlük yapan yaygin türlerden birisidir $^{2}, 9$.

Organik fosforlu insektisitlerin kullanımlarının yasaklandığı günümüzde, sivrisineklerle mücadelede alternatif olarak kullanılmaya başlayan, sonraları sayısı hizla artan ultrasonik ses yayıcılar, istenmeyen bazı organizmaları kaçırmak, öldürmek ya da etkisiz birakmak için üretilmektedirler. Bu cihazlar, hedef türlere bağlı olarak, insanların algıladığı (infrasonik) ya da işitme aralığımızın (ultrasonik) üstüne kadar çok çeşitli akustik spektrumları kapsar. İnfrasonik ses 20 $\mathrm{kHz}$ 'in altındaki sesler olarak nitelendirilirken, ultrasonik sesler ise $18 \mathrm{kHz}$ 'in üzerindeki ses frekansları olarak tanımlanmaktadırlar. Ultrasonik ses yayabilen cihazlar sahip oldukları yüksek enerji düzeylerinden dolayı zararlı eklem bacaklı (örümcekler, akrepler ve böcek zararlıları vb.) ve memelilere karşı kullanılmaktadırlar. Özellikle, Amerika Birleşik Devletleri'nde 2010 yllına kadar geliştirilen söz konusu cihazlardan 20 tanesi patentli olarak piyasaya sürülmüştür ${ }^{10}$.

"Ses" maddeden oluşan bir ortamda yayılan, mekanik bir titreşim dalgasıdır. Ses dalgalar halinde yayılan bir enerji şeklidir sesin tanımı hava, su ya da benzeri bir ortamdaki basınç değişimi olarak tanımlanabilir. Bunun nedeni Sesin, nesnelerin titreşiminden meydana gelen ve uygun bir ortam içerisinde bir yerden başka bir yere, sıkışma (compressions) ve genleşmeler (rarefactions) şeklinde ilerleyen bir dalga olamamasıdır. Örneğin havada yayılan ses, atmosferik basınçta değişiklik yaratır. Bu değişim miktarı ses basıncı olarak isimlendirilir. Bir klinisyene göre ise, işitme duyusunun uyaranı şeklinde tanımlanabilir ${ }^{11}$. Ses büyüklüklerinin en önemlilerinden biri ses basıncıdır. Ses basıncı sesin yayılması sırasında, belirli bir zaman içinde, hava basincinda meydana gelen değişimlerdir. Ses basıncı $\mathrm{p}(\mathrm{t})$; zamana göre değişir ve sinüs formundaki titreşimler ile direkt olarak karakterize edilemez bir büyüklüktür. Basitleştirilmiş formda etkin ses basınc1 p daha kullanışlıdır. Gözlemin yapıldığı $T$ süresince değişen ses basıncından ortalama değer şöyle hesaplanabilir:

$$
P=\sqrt{\frac{1}{T} \int P^{2}(t) d t},[P a]
$$

Burada Pa birimi, Pascal'1 $\left[\frac{N}{m^{2}}\right]$

göstermektedir.

Temel ses basınc1; $1000 \mathrm{~Hz}$ ' de duyma sinırındaki ses basınc1 2.10-5 Pa olarak kabul edilmektedir.

Sesin, kulak tarafindan duyulan yüksekliği, sesin şiddetini ifade' etmektedir. Şiddet sayısal bir çoğunluktur ölçülebilir ve birim alandan, birim zamanda geçen ortalama enerji miktarı olarak tanımlanabilir. Bu da bizi bir seviye ölçüsü olan desibel [dB] birimini kullanmaya götürür. Desibel (dB) ses seviyesini ölçmek ve fiziksel iki değerin oranını ifade etmek için kullanılan logaritmik bir birimdir. dB'nin başka bir anlamı algılanan ses düzeyi ya da gürültü düzeyi birimidir. Ses şiddeti seviyesi için temel ses şiddeti değeri $\mathrm{I}_{0} ; 1000 \mathrm{~Hz}$ deki duyma sinırıdır:

$$
L_{I}=10 . \log \frac{I}{I_{0}}[d B]
$$

Ses şiddeti ses basıncının karesi ile orantılıdır $(I \sim$ $p^{2}$ ). Buradan ses basincı seviyesi:

$$
L_{p}=10 \cdot \log \frac{p^{2}}{p_{0}^{2}}=20 \cdot \log \frac{p}{p_{0}}[d B]
$$

bağıntısı ile bulunur. Buradaki temel ses basıncı $\mathrm{p}_{0}$; $1000 \mathrm{~Hz}$ ' de duyma sinırındaki ses basınc1 2.10-5 Pa olarak kabul edilmektedir. Ses ölçme cihazları bu 
bağıntılar yardımıyla ses basıncı seviyesini doğrudan desibel biriminde gösterirler ${ }^{12}$.

Birim zamandaki basınç değișim miktarı ses frekansı olarak adlandırılır ve Hertz $(\mathrm{Hz})$ cinsinden ölçülür. Ses dalgaları sinüs dalgası şeklindedir. İki tepe arasındaki uzaklık dalga boyu olarak adlandırılır ve bir saniyede gözlenen dalga tepesi sayısına frekans denir. Başka bir deyişle Bir dalganın frekansı, dalganın hava veya başka bir ortam içinden geçerken ortamdaki partiküllerin ne sıklıkta titreştiğine bağlıdır. Frekans ileri geri titreşimlerin zamana bağlı olarak ölçülmesi ile hesaplanır. Saniyedeki titreşim sayısı özel olarak Hertz birimi ile ifade edilir (1Hertz $=1$ döngü/saniye). Sesin ince (tiz) veya kalın (pes) olması frekansına bağlıdır. Sesin frekansı arttıkça incelir (Şekil 1). Bas sesler ise düşük frekanslardadır (Şekil 2). Frekansa bağlı olarak bir sesin ses basinc1 seviyelerinin alınması Frekans Analizi olarak bilinir ${ }^{11,}$ 12.

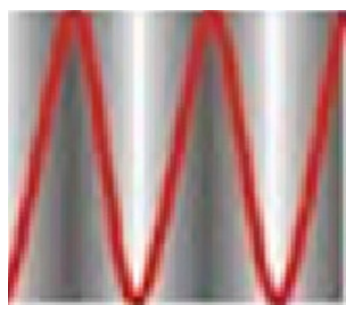

Şekil 1.Yüksek ses frekans1

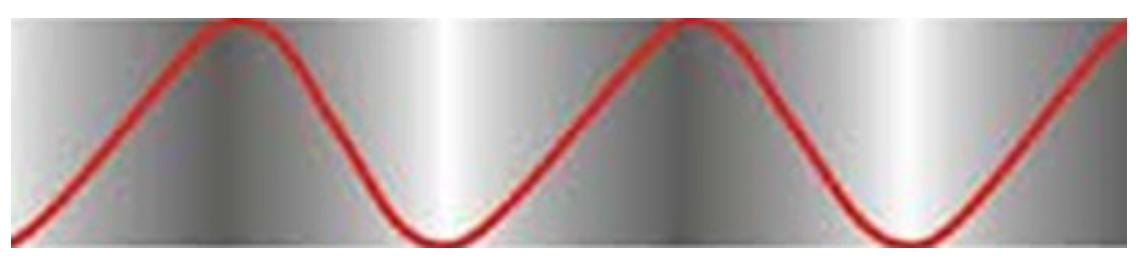

Şekil 2. Düşük ses frekansı
Saniyedeki titreşim sayıs 20000 den fazla $(20 \mathrm{kHz}$ üstü) olan ses titreşimlerine ultrasonik (ses üstü) ses denir. Bazı kaynaklarda bu titreşim sayısı sınırı 16000-20000 (16-20 kHz) aras1 olarak verilmektedir. Günlük hayatta ve teknolojide kullanılan ultrasonik sesler, insan kulağ1 tarafindan duyulamamasına karşın bazı hayvanlar tarafindan (kedi, köpek, yunus) duyulabilmektedir. Ultrasonik ses, titreşim sayısı fazla olduğu için duyulabilen sese göre 100 bin kat daha fazla enerjiye sahiptir. Bu sesler duyulabilen seslere göre daha kolay yönlendirilir ve bu nedenle de teknolojide kullanilir ${ }^{13}$.

\section{GEREÇ VE YÖNTEM}

\section{Sivrisinek larvalarının elde edilmesi}

Çalışmamızın materyal kısmını oluşturan Culex pipiens larvaları, Çukurova Üniversitesi, Tıp Fakültesi, Tıbbi Biyoloji Anabilim Dalı'ndaki insektaryumdan her bir larva evresinden 20'şer tane olacak şekilde alınarak, çalışmanın yapıldığı Karaisalı Meslek Yüksekokulu'nda bulunan Fizik Laboratuvarına getirilmiştir. Her bir frekans için 80 sivrisinek larvası kullanılmış, toplamda 240 larva çalışmaya dahil edilmiştir.

\section{Deney düzeneği}

Deneyimizde, ultrasonik limit ve üstü değerler dahil 5
$\mathrm{kHz}$ ile $35 \mathrm{kHz}$ arasinda frekans aralıkları oluşturabilen ayarlanabilir frekanslı osilatör (Sinyal Jeneratörü) kullanıldı. Ayrıca, çeşitli dB değerlerini ayarlayabilen ve uygulayabilen 400 Watt'llk bir amplifikatör, ses seviyesi ölçüm cihazına (Gürültü Ölçüm Cihazı) ek olarak elde edilen frekansları ölçmek için bir frekans ölçer ve iki adet piezo dönüştürücü içeren sivrisinek larvalarının içine konulduğu 150 ml'lik plastik bir kap kullanılmıştır (Şekil 3). Ayrıca, deney düzeneğinin olmadığ1 ayrı bir kap içerisine de 80 adet sivrisinek larvası kontrol grubunu oluşturmak için konulmuştur.Piezo elektrik özellik sayesinde mekanik bir enerji türü elektrik enerjisine ya da tam tersi olacak şekilde elektrik enerjisi de mekanik enerjiye dönüştürülebilmektedir. Mekanik sıkıştırma sonucunda elektrik üreten, elektrik uygulandığında ise mekanik titreşim elde edilen bazı kristal ve seramiklere ait bir özelliktir.

$\mathrm{Bu}$ deneyde kullandığımız piezo disk materyaline (elektronik devre elemanı olarak düşünebiliriz) belirli frekanslarda kare dalga elektrik enerjisi uygulanmış ve su içerisinde titreşmesi sağlanmıştır. Düzeneğe amplifikatör tarafindan gönderilen frekans değeri arttırıldığında, su içerisindeki titreşim sayısının da arttı̆̆1 gözlemlenmiştir.

\section{Denemeler}

Denemelerden önce, suyun içindeki sıcaklık, nem ve 
ses seviyesinin ölçümleri yapılmıştır. Daha sonra, piezo dönüştürücü deneme kabının içine yerleştirilmiştir.

Yukarıda şekilde verilen düzeneğe bağlı olarak içi su dolu kapta bulunan 1., 2., 3. ve 4. evre sivrisinek larvalarına iki adet basit transdücer tarafindan değişen frekans $(14,8 \mathrm{kHz}, 20,0 \mathrm{kHz}, 26,5 \mathrm{kHz})$ araliklarında ses dalgası her biri 8 saat süren periyotlarda gönderilmiştir. Deneyde farklı yüksek frekanslarda (ultrasonik sınır ve üstü de dahil olmak üzere) oluşturulan ses dalgalarının çeşitli evrelerde bulunan larvalar üzerindeki etkileri incelenmiştir. Deneyde su içerisinde meydana gelen ses şiddeti seviyesi de $\mathrm{dB}$ meter ile ölçülmüştür.

Her bir ses frekansının sivrisinek larvalarında neden olduğu “Toplam Mortalite'yi” (TM) tespit etmek için, 80 larva kabın içine salınmış ve ölü larvalar ses frekansina maruz kaldıktan sonraki 1., 2., 4. ve 8. saatlerde sayılmış ve kaydedilmiştir.

\section{İstatistiksel analiz}

Çalışmada elde edilen veriler, PASW 18.0 programı kullanılarak analiz edilmiştir. Ayrıca anlamlı farklılıklar Tukey's Multiple Range testi kullanılarak tespit edilmiştir.

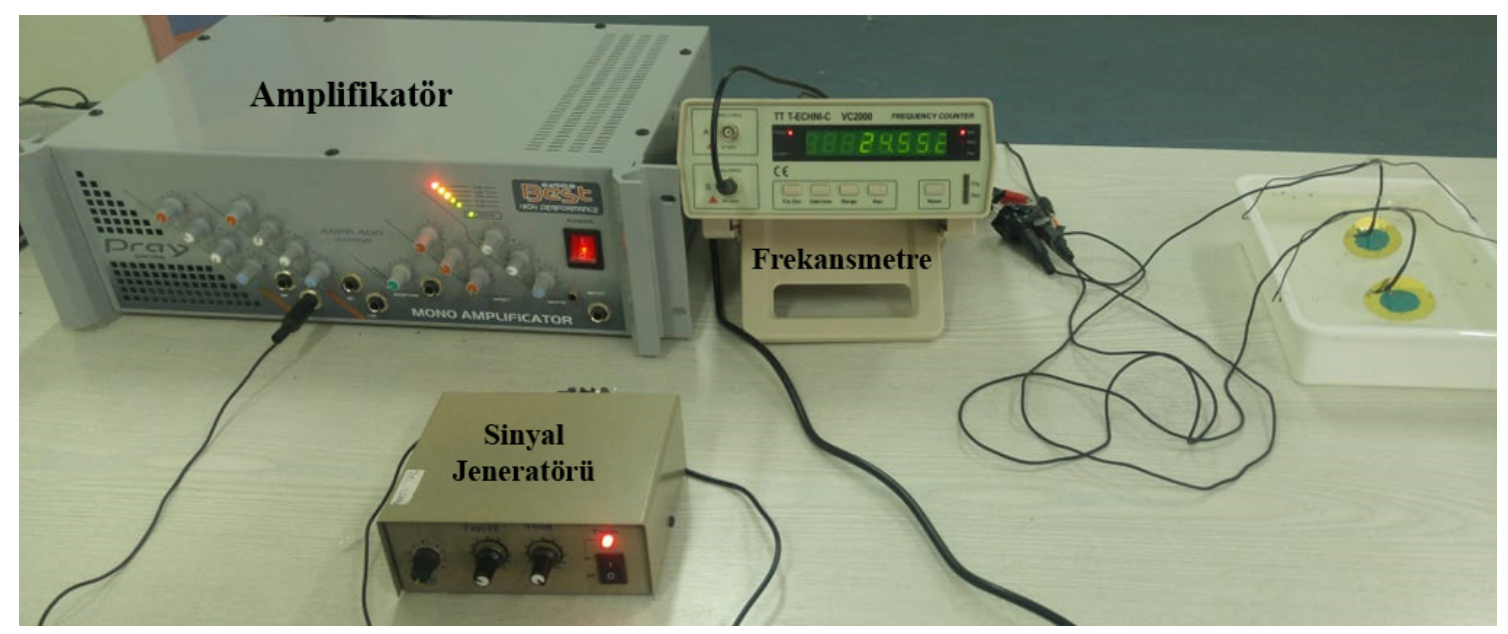

Şekil 3. Deney düzeneği

\section{BULGULAR}

Değişen aralıklarda ultrasonik sınır, ultrasonik sınır altı ve üstü ses frekanslarına maruz birakılan Culex pipiens larvalarında farklı mortal etkiler gözlemlenmiştir. Üç farklı ses frekansında kullanılan
240 sivrisinek larvasından, değişen saat aralıklarında toplam 121 ölü larva tespit edilmiştir. Larval mortalite değerleri; 14,8 kHz'de \%42,14, 20,0 kHz'de \% 23,96 ve $26,5 \mathrm{kHz}$ 'de $\% 33,88$ olarak hesaplanmıştır. Ayrıca ikinci evre larvaların, deney düzeneğine gönderilen tüm frekanslardan en fazla etkilenen evre olduğu gözlemlenmiştir (Tablo 1).

Tablo 1. Denemelerdeki toplam larval mortalite değerleri

\begin{tabular}{|l|c|c|c|c|c|c|}
\hline Ses Frekans1 (kHz)/Ses şiddeti (dB) & $\mathbf{L}_{\mathbf{1}}$ & $\mathbf{L}_{\mathbf{2}}$ & $\mathbf{L}_{\mathbf{3}}$ & $\mathbf{L}_{\mathbf{4}}$ & Toplam Larva/Mortalite & $\mathbf{\%}^{\mathbf{0}}$ \\
\hline $0 / 0$ & 0 & 0 & 0 & 0 & $80 / 0$ & 0 \\
\hline $14.8 / 65$ & 14 & 12 & 12 & 13 & $80 / 51$ & 42.14 \\
\hline $20.0 / 70$ & 10 & 16 & 0 & 3 & $80 / 29$ & 23.96 \\
\hline $26.5 / 76$ & 14 & 18 & 4 & 5 & $80 / 41$ & 33.88 \\
\hline Total & 38 & 46 & 16 & 21 & $240 / 121$ & 100 \\
\hline
\end{tabular}


En fazla mortal etkinin gözlemlendiği ilk deneme, ortalama $25,8^{\circ} \mathrm{C}$ ve $\% 41,4^{\prime}$ lük bir nem oranına sahip laboratuvar koşullarında gerçekleşmiştir.

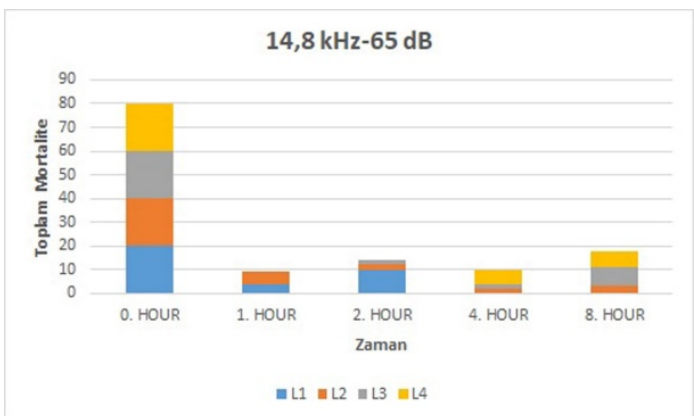

Şekil 4. Sekiz saatlik periyotta $14,8 \mathrm{kHz}$ 'de ultrasonik altı ses frekansına maruz kalan Culex pipiens larvalarının mortalite değerleri.

Düzeneğe, 65 desibellik bir ses şiddetinde gönderilen, $14,8 \mathrm{kHz}$ 'lik ultrasonik altı frekans değeri, 2. ve 3. evre larvalarda eşit oranda mortal etkiye sahip olmuş ve 4 . evre larvalarda sekiz saat süren deneme sonrasinda 13 adet ölü larva kaydedilmiştir. Denemede en fazla mortalite kaydı 4-8. saatler arasında gerçekleşmiştir (Şekil 4). Çalışmamızın ikinci denemesinde, ortalama 26,6 ${ }^{\circ} \mathrm{C}^{\prime}$ lik sicaklıkta ve \% 54,6 nem içeren oda koşullarında, 70 desibellik şiddete sahip olan 20,0 $\mathrm{kHz}$ 'lik ultrasonik sınırdaki ses frekansı kullanılmıştır. En az larval mortalitenin gözlemlendiği denemede, ikinci evre larvalardan 16 ölümün kaydedilmiş, 4. evre larvalardan sadece 3 ölüm gözlemlenmiştir. Söz konusu frekansta 4-8. saatler arasinda en fazla mortaliteye rastlanılmıştır (Şekil 5).

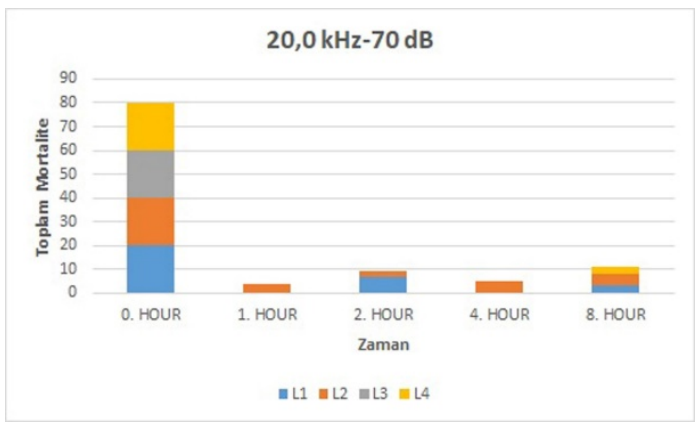

Şekil 5. Sekiz saatlik periyotta 20,0 kHz'de ultrasonik altı ses frekansına maruz kalan Culex pipiens larvalarının mortalite değerleri.

Ultrasonik sınır üstü ses frekansı olan $26,5 \mathrm{kHz}$ 'in mortal etkisinin değerlendirildiği, ortalama $27,6{ }^{\circ} \mathrm{C}$ sicaklık ve $\% 55,4$ nem oranın ölçüldüğ̈̈ son denemede, toplamda 41 larval ölüm kaydedilmiştir.
İkinci evre larvaların en fazla mortalite gösterdiği denemede, 4-8. saatler arasindaki periyot, yine en fazla ölüm kaydedilen zaman dilimi olarak saptanmıştır (Şekil 6).

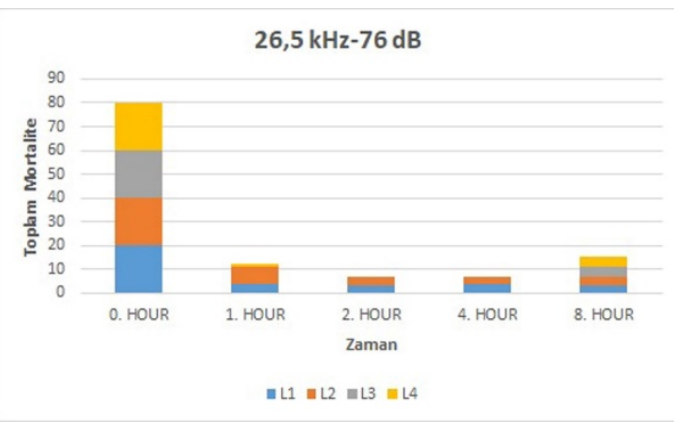

Şekil 6. Sekiz saatlik periyotta $26,5 \mathrm{kHz}$ 'de ultrasonik altı ses frekansina maruz kalan Culex pipiens larvalarının mortalite değerleri.

Tablo 2. Ses frekansı değişkenine göre Culex pipiens larvalarının mortalite düzeylerindeki farkı gösteren tek yönlü varyans analizi sonuçları

\begin{tabular}{|l|c|c|c|c|c|c|}
\hline $\begin{array}{l}\text { Frekans } \\
\text { Grupla1 }\end{array}$ & $\mathbf{N}$ & $\mathbf{X}$ & SS & $\mathbf{F}$ & $\mathbf{P}$ & $\begin{array}{c}\text { Anlamlı } \\
\text { Farklılik }\end{array}$ \\
\hline Kontrol & 16 & .00 & .00 & & & $\begin{array}{c}14.8 \\
\mathrm{kHz}- \\
26.5 \mathrm{kHz}\end{array}$ \\
\hline $\begin{array}{l}14,8 \\
\mathrm{kHz}\end{array}$ & 16 & .88 & 1.204 & 11.400 & .000 & \\
\hline $\begin{array}{l}20.0 \\
\mathrm{kHz}\end{array}$ & 16 & 1.81 & 2.373 & & & \\
\hline $\begin{array}{l}26,5 \\
\mathrm{kHz}\end{array}$ & 16 & 3.44 & 2.250 & & & \\
\hline Toplam & 64 & 1.53 & 2.130 & & & \\
\hline
\end{tabular}

$\mathrm{N}$, örneklem grupları; X, ortalamalar; SS, standart sapma; F, frekans; $\mathrm{P}$, anlamlllik

Bulgularımızın istatistiksel analiz sonuçlarına göre; $14,8 \mathrm{kHz}$ ve $26,5 \mathrm{kHz}$ 'nin Culex pipiens larvalarında neden olduğu mortalite değerleri arasında anlamlı bir ilişki olduğu saptanmıştır ( $\mathrm{p}<0,05)$ (Tablo 2).

\section{TARTIŞMA}

Doğadaki tüm canlılarda, yüksek ses frekanslarının oluşturduğu etkiye karşı gözlemlenen morfolojik ve fizyolojik değişimler söz konusudur. Sivrisineklerde, değişen aralıklardaki yüksek ses frekanslarının (ultrasonik sınır, ultrasonik üstü ve altı) etkileri belirli seviyelerde mortal etki olarak gözlemlenmektedir. Akustik rezonans tüm biyolojik yapiların sahip olduğu canlıdan canlıya farklılık gösteren bir iç frekans değeridir. Sivrisinek larvalarının akustik 
rezonans sınırına ulaşan ses frekansına bağlı titreşimler, mortal etkilerini larvalar üzerinde göstermeye başlarlar. Sivrisinek larvalarının başgövde birleşim bölgesinde bulunan ve çok narin bir yapıya sahip olan hava keseciklerinin bu sinırın aşılması ile birlikte deformasyona uğraması, sivrisinek larvalarında akut travma ve embolinin görülmesine ve ardından da ölümlerine neden olmaktadır. Ayrıca, akustik rezonans değerine yakın frekansların ürettiği titreşimlere, uzun süreli olan maruziyetin, çalışmamızda 4-8 saat arası larval mortaliteyi arttırdığ1 düşünülmektedir ${ }^{14}$.

Yerleşim alanlarında bir çevre sağlığı sorunu olarak nitelendirilen sivrisinekler ile mücadele yöntemleri arasına, yukarıda bahsedilen etkilerinden dolayı alternatif bir çözüm olan ses frekansları da kullanılmaktadır. Sivrisinekler, esas olarak 4 önemli hastalık etmenini (sıtma, sarı humma, dank humması ve filarya) insanlara bulaştırarak sağlık açısından problemlere neden olurlar ${ }^{6}$. Özellikle sitma, hücre içi, protozoon kaynaklı bir enfeksiyon hastalığıdır. Sivrisinekler tarafindan insanlara "salivarian" bulaşma şekli ile bulaşır. Etkili tedavisi olmasına rağmen, dünyada halen önde gelen ölüm nedenlerinden biri olarak önemini korumaya devam etmektedir ${ }^{2}, 15$.

Ergin formlarına tek başına etkisiz olarak tespit edilen ultrasonik ses frekanslarının sivrisinek larvalarına olan etkisi önceden yapılan çalışmalarda belirlenmiștir ${ }^{16,}{ }^{17}$. Sivrisineklerin erken larval evrelerine $\left(\mathrm{L}_{1}\right.$ ve $\left.\mathrm{L}_{2}\right)$ 14,0 kHz-20,0 kHz aras1 ses frekanslarının daha fazla mortal etkisi olduğu gözlemlense de $20,0 \mathrm{kHz}$ üstü aralıklarda geç larval evrelere daha fazla gözlemlenen mortal etkiler saptanmıştır ${ }^{18}$. Culex pipiens larvalarının kullanıldığ çalışmamızda, piezo transdüktörünün bağlandığı su kabına değișen yüksek oranlarda ses frekansları gönderilmiştir. En fazla larval mortaliteye sebep olan frekansın $14,8 \mathrm{kHz}$ olduğu saptanmıs ve bu frekans değerinin erken evre larvaları daha fazla etkilediği gözlemlenmiştir. Ultrasonik sinır üstü frekans değerimiz olan 26,5 kHz'de ise geç evre larvalar ultrasonik sınır ve altı frekanslara göre daha fazla etkilenmiş olsa da erken evre larvalarda yukarıda bahsedilen bulguların aksine 26,5 kHz'de daha fazla larval ölüm saptanmıştır. Bu farklılığın, 26,5 kHz’in kullanılan Culex pipiens geç evre larvalarının akustik rezonans değerine yakın bir miktarda titreşim üretmesinden kaynaklandığ1 tarafimızca düşünülmektedir. Bulgularımızın istatistiksel analizi sonucunda, $14,8 \mathrm{kHz}$ ve $26,5 \mathrm{kHz}$ 'in mortalite değerleri arasındaki anlamlı farklılık, sırasıyla erken ve geç evre sivrisinek larvalarının akustik rezonans değerlerine yakın değerlerde olduklarından ortaya ç1ktı̆̆1 düşünülmektedir (Tablo 2).

İçme suyu tanklarında Aedes aegypti larvaları için gerçekleştirilen bir çalışmada kullanılan larvasonik cihaz, hedef canlı populasyonunda bir dakikalık bir sürede \% 90 ve üstü mortal etkiye sebep olmuştur. Kullanılan cihazdaki transdüktör sayısının, gücünün belirtilmemesi söz konusu etkiyi netleştirememektedir. Ayrıca deney düzeneğimizden daha güçlü olduğu düşünülen söz konusu cihazın, hedef-dışı organizmalara olan etkisi de bilinmemektedir ${ }^{19,}, 20$.

Ultrasonik banyo adı ile bilinen ve genel amac1 sterilizasyon olan diğer bir cihaz ile yapılan çalışmada Anopheles ve Culex türleri kullanılmış ve 180 saniyede $\% 90$ üstü mortal etki tespit edilmiştir. Söz konusu cihazın, çalışma prensibi bilinmemekle birlikte deneysel bir düzenek değildir ${ }^{21}$.

Sonuç olarak, vektör eklem bacaklı sivrisineklerin, larval mücadelesinde en çok kullanılan kimyasal ve biyolojik mücadele ajanlarının yanında, ultrasonik sınırlardaki yüksek ses frekanslarının larvaların yaşam ortamları olan suda oluşturduğu titreşimlere dayalı olan mücadele ajanları, alternatif çözümler olarak düşünülebilir. Ayrıca, hedef-dışı organizmalara etkisi olduğu bilinen kimyasal mücadele ajanlarından ultrasonik sınırda yüksek ses frekansı üreten cihazların çevreye olan etkisi bakımından daha avantajlı olduğu düşünülebilir. Bu prensip ile çalışan cihazların sayısının sivrisinekler ile mücadelenin sıklıkla yapıldığı bölgelerde artması, hem maddi hem de çevresel kaygıların azalması yönünde konu ile ilgili yöneticilere katkı sağlayacağını düşünmekteyiz.

\footnotetext{
Yazar Katkılar: Calısma konsepti/Tasarımı: HÖ; Veri toplama: HÖ, HK; Veri analizi ve yorumlama: HÖ, HK; Yazı taslağı: HÖ, HK; İçeriğin eleştirel incelenmesi: HÖ, HK; Son onay ve sorumluluk: HÖ, HK; Teknik ve malzeme desteği: HK; Süpervizyon: HÖ, HK; Fon sağlama (mevcut ise): yok.

Hakem Değerlendirmesi: Diș bağımsız.

Çıkar Çatışması: Yazarlar çıkar çatışması beyan etmemişlerdir.

Finansal Destek: Bu çalışma, "FBA-2018-9933" numaralı bireysel araştırma projesi ile Çukurova Üniversitesi, Bilimsel Araştırma Projeleri Koordinasyon Birimince deteklenmiştir.

Author Contributions: Concept/Design : HÖ; Data acquisition: HÖ, HK; Data analysis and interpretation: HÖ, HK; Drafting manuscript: $\mathrm{HO}, \mathrm{HK}$; Critical revision of manuscript: HÖ, HK; Final approval and accountability: HÖ, HK; Technical or material support: HK; Supervision: HÖ, HK; Securing funding (if available): $\mathrm{n} / \mathrm{a}$. Peer-review: Externally peer-reviewed.

Conflict of Interest: Authors declared no conflict of interest. Financial Disclosure: Authors declared no financial support
} 


\section{KAYNAKLAR}

1. Özkul A, Yıldırım Y, Pınar D, Akçalı A, Yılmaz V, Çolak D. Serological evidence of West Nile Virus (WNV) in mammalian species in Turkey. Epidemiol. Infect. 2006;134:826-9.

2. İnci A, Düzlü Ö. Vektörler ve vektörlerle bulaşan hastalıklar. Erciyes Üniv Vet Fak Derg. 2009;6:53-63.

3. Kavur H, Deveci Ö, Boyacioğlu H. Kitin sentez inhibitörü Diflubenzuron'un Culex pipiens (L.) ve Culiseta longiareolata (Macquart)'nın (Diptera: Culicidae) larvaları üzerine etkileri. Turkiye Parazitol Derg. 2011;35:154-8.

4. Günay F, Alten B, Simșek F, Aldemir A, Linton YM. Barcoding Turkish Culex mosquitoes to facilitate arbovirus vector incrimination studies reveals hidden diversity and new potential vectors. Acta Tropica 2015;143:112-20.

5. WHO (World Health Organization), World Malaria Report. 2005.

6. Alten B, Çağlar SS. Vektör Ekolojisi ve Mücadelesi, T.C. Sağlık Bakanlığ1 Sağlık Projesi Genel Koord., Ankara, Bizim Büro Basımevi, 1998.

7. Berg H, Zaim M, Yadav RS, Soares A, Ameneshewa B, Mnzava A et al. Global trends in the use of insecticides to control vector-borne diseases. Environ Health Perspect. 2012;120:577-82.

8. Caglar SS, Alten B, Bellini R, Simsek FM, Kaynas S. Comparison of nocturnal activities of mosquitoes (Diptera: Culicidae) sampled by New Jersey light traps and $\mathrm{CO} 2$ traps in Belek, Turkey. J Vector Ecol. 2003;28:1-11.

9. Faulde MK, Spiesberger M, Abbas B. Sentinel siteenhanced near-real time surveillance documenting west nile virus circulation in two Culex mosquito species indicating different transmission characteristics, Djibouti City, Djibouti. J Egypt Soc Parasitol. 2012;42:461-74.

10. Aflitto N, DeGomez T. Sonic Pest Repellents. The University of Arizona Cooperative Extension. 2014;14.

11. Özkurt H, Altuntaş Ö. The effects of sound waves upon plant nutrient elements uptake of sword Fern (Nephrolepis Exaltata) plants. J Basic Appl Sci Res. 2016;6:9-15.

12. Cetinkaya A. The sound analysis of some insect species and the investigation of availability, agricultural struggle (Msc Thesis). Adana, Çukurova University. 2010.

13. İșçi C. Ultrasonik ve diğer sivrisinek kovucular. Journal of Yasar University. 2006:1;293-301.

14. Nyberg MH, Nyberg HJ. U.S. Patent No. 4, 284,845, 8/1981.

15. Kuşcu F, Öztürk DB, Gül S, Babayiğit ML. Adana'da 2002-2012 y1llar1 arasinda sitma epidemiyolojisi. Turkiye Parazitol Derg. 2014;38:147-50.

16. Fredregill CL, Motl GC, Dennett JA, Bueno R, Debboun M. Efficacy of two Larvasonic ${ }^{\mathrm{TM}}$ units against culex larvae and effects on common aquatic nontarget organisms in Harris County, Texas. J Am Mosq Control Assoc. 2015;31:366-70.

17. Okorie PN, Okareh OT, Adeleke O, Falade CO, Ademowo OG. Effects of an in-built ultrasonic device on Anopheles gambiae s.l mosquitoes in an indoor environment. International Research Journal of Engineering Science, Technology and Innovation. 2015;4:5-11.

18. New Mountain. Basics of Acoustics. http://www.newmountain.com/education. (Erişim Ocak 2019).

19. LaLiberte G, Haber E. Literature Review of the Effects of Ultrasonic Waves on Cyanobacteria, Other Aquatic Organisms, and Water Quality. Wisconsin Department of Natural Resource. Research Report. 2014.

20. Britch SC, Nyberg H, Aldridge RL, Swan T, Linthicum KJ. Acoustic control of mosquito larvae in artificial drinking water containers. J Am Mosq Control Asso. 2016;32:341-4.

21. Khalfia NO, Ibrahim DSA, Khairy RMY, Omer RMY. The effect of the ultrasound waves on mosquitoes. College of Science Department of Scientific Laboratories-Physics research group. Sci Rep. 2016. 